\section{HSE}

Historia Social y de la Educación

Social and Education History
Hipatia Press

www.hipatiapress.com

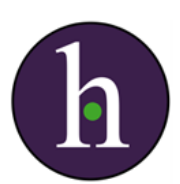

Instructions for authors, subscriptions and further details:

$\underline{\text { http://hse.hipatiapress.com }}$

\title{
Transnationalism, Gender and History of Education
}

Garazi López de Aguileta ${ }^{1}$

1) Universitat de Barcelona (España)

Date of publication: October $23^{\text {rd }}, 2017$

Edition period: Edition period: October 2017-February 2018

To cite this article: López de Aguileta, G. (2017). Transnationalism, Gender and History of Education [Review of the book]. Social and Education History 6(2), 346-348. doi: 10.17583/hse.2017.2689

To link this article: http://dx.doi.org/10.17583/hse.2017.2689

\section{PLEASE SCROLL DOWN FOR ARTICLE}

The terms and conditions of use are related to the Open Journal System and to Creative Commons Attribution License (CC-BY). 


\section{Reviews (II)}

Raftery, D., \& Clarke, M. (2016). Transnationalism, Gender and History of Education. Routledge.

$\mathrm{s}$ the title clearly summarizes, the book collects eleven pieces of A research (one per chapter) conducted by a number of international 1 scholars whose work is centred on the research of gender and the history of education (19th and mid-20th century education) with a focus on transnationalism and religion. The eleven chapters of this book tell stories from all over the world (Europe, America and the European colonies in Asia and Africa) about how transnationalism shaped different educational projects, on the one hand, and how gender played a crucial role in many of those projects that were motivated by gender issues on the other hand. The research exposed in this book goes from Teaching Sisters and missionaries who were transnational actors and made use of international networks to create global educational practices and projects; going through female educators who made use of transnational networks to educate women all over the world to use their right to vote; to Christian Brothers who supported their educational aim of reshaping Ireland with a religious, nationalist magazine.

The first chapter, "Teaching Sisters and transnational networks: recruitment and education expansion in the long nineteenth century", studies the transnational networks the Teaching Sisters used to develop educational practices worldwide, building global networks of convents and schools and recruiting new members to expand these networks.

Chapter number two, "Education for girls in Ireland: secondary and vocational curricular provision 1930-1960" draws a comparison between secondary education and vocational education linked to women, centred in 2017 Hipatia Press

ISSN: 2014-3567

DOI: $10.17583 /$ hse.2017.2689

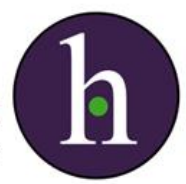




\section{López de Aguileta - Gender and History of Education [Review]}

Ireland. Women had limited jobs they could access to, and vocational education prepared them for these gender- and class-stratified jobs. However, research shows that women who had studied secondary education were more successful than the ones who had done vocational education.

The third chapter, "Gender, cosmopolitanism and transnational space and time: Kasuya Yoshi and girls' secondary education" narrates the career of a teacher in Tokyo who had travelled around Europe and the US with the aim of providing secondary and higher education to girls. She made a comparative text on education in different countries, with the belief that an educated woman in Japan should take elements of education from other countries.

The following chapter, "Beyond centre and periphery: transnationalism in tow teacher/suffragettes' work", describes two English suffragettes who did transnational work through England, Australia, New Zealand and South Africa with the aim of educating women in different countries to use their right to vote. Among their work, they established links with different women's political organizations and created a free Kindergarten in Australia. Chapter number five, "Teaching morality and religion in nineteenth-century colonial Algeria: gender and the civilizing mission", studies French missionaries who were established in Algeria in order to educate girls and convert them into Christianity. Although in French classes they were forbidden to teach the students anything related to Christianity, they somehow managed to do so through the use of religious maxims.

The sixth chapter, "Our Boys: the Christian Brothers and the formation of youth in the "new Ireland' 1914-1944", changes the focus from women to men and studies how the Irish Christian Brothers used education to reshape the country. They promoted their educational values with a very influential magazine, Our Boys, which was "ultra-nationalist, ultra-catholic and Anglophobic".

In the next chapter, "Mobilizing Mother Cabrini's educational practice: the transnational context of the London school of the Missionary Sisters of the Sacred Heart of Jesus 1898-1911", the author highlights the educational life of Italian Mother Cabrini, an active transnational networker, who founded a missionary institute called the Missionary Sisters of the Sacred Heart of Jesus (MSC). As her work progressed, she established 51 MSC schools in America and Europe and a Sacred Heart College in England. 
The eighth chapter, "'A position of usefulness': gendering history of girls' education in colonial Hong Kong (1850s-1890s)", analyzes British missionaries in colonial Hong Kong whose objective was to educate girls as Christians to be good wives. It highlights the stories of some Eurasian girls who, even though were regarded very negatively in both Chinese and European societies (they were thought of as evidence of "moral irregularity"), achieved to get a Christian education and job positions as teachers.

The ninth chapter, "Teacher mobility and transnational, 'British World' space: the League of the Empire's 'Interchange of Home and Dominion Teachers', 1907-1931", presents research conducted on British teachers (mainly female) who participated in transnational networks through which they were mobilized and exchanged over the colonies of the British Empire. The tenth chapter, "They came with a purpose: educational journeys of nineteenth-century Irish Dominican Sister Teachers", studies the lives and work of ten Irish Dominican Sisters who travelled to New Zealand with educational purposes. Although they encountered difficulties and barriers on their way there and when establishing in Dunedin, they used informal transnational networks to establish schools in the 'New World'.

The last chapter, "William Graham Brooke (1835-1907): advocate of girls' superior schooling in nineteenth-century Ireland", narrates Brooke's engagement in facilitating women access to higher education and university. As a man who was connected to different educational institutions, he wanted women to engage with these same institutions.

All in all, the book gives an overview of what 19th and mid-20th century education looked like worldwide. It depicts the lives of different missionaries, teachers and researchers who were linked by one main feature: they were somehow engaged in transnational networks which they used to try to facilitate and bring education to women both in European and American countries as well as in European colonies

Garazi López de Aguileta Universitat de Barcelona garazi.jaussi@gmail.com 